Berkala Ilmu Perpustakaan dan Informasi, Vol. 14, No. 2, Desember 2018, Hal. 204-213 DOI: 10.22146/bip.37876

ISSN 1693-7740 (Print), ISSN 2477-0361 (Online)

Tersedia online di https://jurnal.ugm.ac.id/bip

\title{
Perubahan makna perpustakaan
}

\author{
Purwani Istiana $^{1}$, Faruk HT ${ }^{2}$ dan Suzie Handayani ${ }^{2}$ \\ ${ }^{1}$ Sekolah Pascasarjana, Universitas Gadjah Mada, Yogyakarta \\ ${ }^{2}$ Fakultas Ilmu Budaya, Universitas Gadjah Mada, Yogyakarta \\ Email:nina@ugm.ac.id
}

Naskah diterima: 6 Agustus 2018, direvisi: 5 September 2018, disetujui: 16 Oktober 2018

\begin{abstract}
ABSTRAK
Pendahuluan. Perubahan realita perpustakaan sesungguhnya merupakan satu bentuk komunikasi bahasa oleh pengelola perpustakaan. Bahasa mengenai perpustakaan, merupakan representasi perpustakaan melalui Bahasa. Berbagai definisi perpustakaan yang tersedia pada berbagai literatur merupakan representasi perpustakaan melalui Bahasa. Penelitian ini bertujuan untuk mengetahui perubahan makna perpustakaan dari waktu ke waktu.

Metode penelitian. Metode dan analisis data yang digunakan dalam penelitian ini adalah metode diskursif genealogi. Pengumpulan data dilakukan melalui dokumentasi berbagai wacana tentang perpustakaan.

Data analisis. Analisis data dengan melihat perubahan makna perpustakaan dari waktu ke waktu, sehingga diperoleh satu kesimpulan makna perpustakaan mutakhir.

Hasil dan Pembahasan. Hasil penelitian menunjukkan bahwa makna perpustakaan terus berubah. Makna perpustakaan mutakhir adalah sebuah ruang atau institusi, tempat dikumpulkannya berbagai informasi, serta mempertemukan berbagai kebutuhan pengguna, terhadap ruang, layanan, dan berbagai sumberdaya, untuk kepentingan pendidikan, penelitian, informasi dan rekreasi.

Kesimpulan dan Saran. Berbagai perubahan makna perpustakaan dari waktu ke waktu menunjukkan bahwa representasi perpustakaan melalui bahasa mengalami perubahan. Perpustakaan merupakan makna, yang dapat berubah dan dikontruksi.
\end{abstract}

Kata Kunci: Makna Perpustakaan; Representasi Perpustakaan; Representasi Bahasa

\section{ABSTRACT}

Introduction. The changing reality of libraries actually is a form of communication by the library management. The Language of libraries, is a representation of libraries through language. Various definitions of libraries from the literatures are representations of libraries through language. This study aims to examine the changing meaning oflibraries from time to time.

Data Collection Method. Data collection was conducted by involving documentation of various discourses discussing libraries.

Analysis Data. Discursive genealogy was used to analyse the data to provide changes of meaning of libraries from time to time.

Results and Discussions. The result showed that the meaning of libraries continues to change. The current meaning of libraries is a room or institution where information is stored and gathered. Libraries are hubs of users' needs including space, services, and various resources to support education, research, information, and recreation.

Conclusion. Various changes of meaning of Libraries from time to time show that the representation of libraries through language has changed. The meaning oflibraries may change and deconstruct.

Keywords: The Meaning of the Library; Library Representation; Language Representation 


\section{A. PENDAhULUAN}

Kita ketahui bahwa perpustakaan berkembang dengan cepat. Hadirnya teknologi informasi, perpustakaan secara fisik (tempat) dan perpustakaan dalam pengertian pusat informasi, semakin tumbuh. Disebutkan dalam Encyclopedia Britannica, bahwa perpustakaan dapat dikatakan mulai ada sejak catatan disimpan dan pada saat itu, tidak ada perbedaan antara ruang arsip dan perpustakaan pada saat itu. Hal ini juga dikatakan oleh (Tucker \& Goedeken, 2017) bahwa asal mula perpustakaan, para sejarawan menyimpulkan bahwa tanda dimulainya era bersejarah tentang perpustakaan adalah penemuan tulisan dikombinasikan dengan dorongan untuk melestarikan prasasti dan hal-hal tertulis.

Perpustakaan dalam realitas dapat kita pelajari dalam sejarah perkembangan perpustakaan. Sejarah perkembangan perpustakaan di mulai sejak pada era klasik (SM-300 M). Pada era klasik perpustakaan sebagai tempat dokumen penting, tidak semua orang dapat mengakses perpustakaan. Walaupun pada akhir era ini sudah muncul kesadaran untuk membangun perpustakaan umum. Di abad pertengahan (400-1400), perpustakaan mulai mengangkat pustakawan sebagai penjaga buku, kekhawatiran yang luar biasa terhadap kehilangan buku. Buku dipasang rantai, dan dikaitkan dengan rak buku. Era Modern (1500-1800), kekhawatiran terhadap hilangnya buku masih terlihat. Pada era modern muncul perpustakaan yang dibangun dengan dana pribadi atau kelompok. Periode Perpustakaan Kontemporer (1900-2000) mulai dikenal otomasi perpustakaan, buku elektronik, serta koleksi berbentuk micro. Setelah tahun 2000, merupakan perpustakaan era teknologi informasi. Perpustakaan era teknologi informasi memunculkan konsep perpustakaan digital, perpustakaan tanpa dinding. Perpustakaan digital berarti bahwa bentuk atau format perpustakaan adalah digital (Saleh, 2010).

Perubahan realitas perpustakaan yang tergambar dalam sejarah perkembangannya, sesungguhnya merupakan satu bentuk komunikasi bahasa oleh pengelola perpustakaan. Representasi perpustakaan melalui bahasa juga dapat ditemukan dalam berbagai definisi perpustakaan. Dengan kata lain berbagai definisi perpustakaan merupakan representasi perpustakaan melalui bahasa. Definisi perpustakaan dari waktu ke waktu mengalami perubahan. Hal ini berarti bahwa perpustakaan merupakan sebuah makna. Makna Perpustakaan seperti juga pada realitas perpustakaan mengalami perubahan. Tujuan penelitian ini adalah mengetahui perubahan makna perpustakaan dari waktu ke waktu, serta mengetahui makna perpustakaan mutakhir saat ini yang terepresentasikan melalui bahasa.

Kajian terkait makna perpustakaan beberapa telah dilakukan, antara lain oleh Yusnita (2012), yang mengkaji makna perpustakaan oleh anak yang berkebutuhan khusus dalam hal ini tuna netra. Penelitian lain yaitu oleh Pradana (2014) meneliti makna perpustakaan oleh Kepala Sekolah, bagaimana mereka menggambarkan tentang perpustakaan sekolah. Penelitian (Yusnita, 2012; Kawindra, 2013), keduanya menggunakan metode fenomenologi. Penelitian (Pradana, 2014), tentang makna perpustakaan, bagaimana anak jalanan memaknai perpustakaan. Penelitian yang lebih baru tentang makna perpustakaan di Indonesia dilakukan oleh (Utami, 2016) yang meneliti tentang bagaimana kontruksi makna perpustakaan desa oleh masyarakat. Kee mpat penelitian terdahulu tidak membahas tentang perubahan makna perpustakaan, namun lebih pada bagaimana pengguna memaknai perpustakaan. Penelitian terkait makna dan juga masih dengan obyek perpustakaan adalah penelitian yang dilakukan oleh (Saputra, Damayani, \& Rahman, 2017), dengan menggunakan metode fenomenologi mengkaji makna pegiat Perpustakaan Jalanan. Dengan demikian penelitian yang dilakukan oleh peneliti tentang perubahan makna perpustakaan belum pernah dilakukan sebelumnya. Hal ini penting dilakukan untuk mengetahui perubahan makna perpustakaan dari waktu ke waktu. Makna perpustakaan selalu diterima apa adanya seperti yang telah diwacanakan. Oleh karena itu, kajian ini memperkaya keilmuan di bidang perpustakaan dan memberikan sumbangan yang berarti bagi pengembangan ilmu perpustakaan. 


\section{B. TINJAUAN PUSTAKA Representasi}

Penelitian ini menggunakan teori representasi Hall. Representasi menurut Hall (2003) adalah proses di mana anggota anggota suatu budaya menggunakan bahasa untuk memproduksi makna. Singkatnya Hall mengatakan bahwa representasi adalah produksi makna melalui bahasa. Representasi melibatkan tiga perintah yang berbeda yaitu benda, peristiwa, orang atau pengalaman; konsep mental yang ada di kepala kita dan tanda-tanda. Di sini terlihat bahwa dalam representasi berhubungan dengan tanda-tanda dan konsep mental yang ada di kepala kita. Representasi menurut Hall (2003) merupakan kebutuhan dasar untuk berkomunikasi, karena tanpa representasi kita tidak mampu berkomunikasi satu dengan yang lain, representasi utamanya tentang makna akan mengarahkan kepada pemahaman. Bahasa yang dimaksudkan oleh Hall (2003) adalah bahasa dalam arti luas yaitu bahasa lisan, bahasa tulis, bahasa musik, bahasa tubuh, ekspresi wajah, gambar visual dan sebagainya. Menurut Hall (2003) bahasa dalam arti luas tersebut digunakan untuk mewakili (merepresentasikan) apa yang kita ingin katakan, ekspresikan dan komunikasikan tentang sebuah pikiran, konsep, ide atau perasaan.

Teori Stuart Hall tentang representasi, banyak digunakan untuk satu konsep atau fenomena direpresentasikan. Seperti dalam kajian Aprinta E.B. (2011) menggunakan teori hall representasi untuk mengkaji konsep "Girl Power Wanita Modern" dalam media online. Penelitian Wuryanto (2016) juga menggunakan teori representasi Stuart Hall yakni bagaimana identitas perempuan berhijab direpresentasikan dalam iklan. Bagaimana gaya hidup mahasiswa direpresentasikan dalam sebuah novel (Vacliuca \& Yasir, 2016) juga dikaji menggunakan teori Stuart Hall ini. Oleh karena itu, konsep perpustakaan dalam penelitian ini dikaji pula menggunakan teori representasi Stuart Hall.

\section{METODE PENELITIAN}

Penelitian ini menggunakan pendekatan kualitatif, dengan metode diskursif genealogi. Metode yang digunakan dalam penelitian ini adalah metode diskursif genealogis. Pengumpulan data dokumentasi yakni berbagai wacana dan pernyataan mengenai perpustakaan dari berbagai sumber literatur. Metode yang dimaksud di sini sekaligus digunakan untuk analisis data. Metode diskursif genealogis merupakan metode yang berfokus pada serangkaian pernyataan-pernyataan yang membentuk realitas sosial (Kumbara, 2018)

\section{HASIL DAN PEMBAHASAN}

Hasil penelitian menunjukkan perubahan makna perpustakaan. Melalui analisis perubahan definisi terlihat perubahan makna perpustakaan. Sebagaimana disebutkan oleh (Hall, 2003) bahwa bahasa merupakan sistem representasi ke dua. Berbagai konsep diterjemahkan ke dalam bahasa yang umum. Demikian juga konsep "perpustakaan", yang dituangkan melalui bahasa, merupakan representasi perpustakaan oleh masyarakat atau orang-orang yang menggunakan konsep tersebut.

Beberapa konsep "perpustakaan” direpresentasikan melalui bahasa:

Perpustakaan berasal dari kata "pustaka", atau "libre "(bahasa Latin)yang berarti buku. The world Publishing Company (1970), mendefinisikan perpustakaan:

"Library is a room or building where a collection of books, etc. is keptfor reading or reference".

Dalam kamus (The world Publishing Company, 1970), disebutkan bahwa:

"Library is a public or private institution in charge of the care and circulation of such a collection" 
Pada kedua representasi perpustakaan melalui bahasa tersebut di atas, makna perpustakaan dapat disimpulkan bahwa perpustakaan merupakan suatu ruang, gedung atau institusi dimana koleksi buku-buku dan sebagainya (tidak dijelaskan lain-lainnya apa saja, jenis pustaka lainnya, selain buku) disimpan, dirawat untuk dibaca atau sebagai sumber rujukan, dan juga buku-buku tersebut dapat dipinjamkan.

Kamus (Macmillan, 1973), menyebutkan

"library is collection of books or other literary, artistic, or reference material." Dan juga "library is room or building containing such a collection".

Tiga tahun kemudian, perpustakaan direpresentasikan dengan menyebutkan koleksi selain buku. Koleksi lain yang ada di perpustakaan adalah bahan sastra, artistik, serta bahan referensi lainnya. Makna perpustakaan sebagai ruang atau gedung tempat menyimpan koleksi masih tetap, namun ada tambahan koleksi selain buku.

Dalam "Collins English Dictionary - Complete \& Unabridged 10th Edition, (1979)“ disebutkan bahwa:

"Library is a room or set of rooms where books and other literary materials are kept"

Representasi perpustakaan dalam kamus tersebut merupakan ruangan, dapat pula dimaknai sebagai tempat buku dan material lainnya disimpan. Artinya sebuah ruangan yang berisi buku-buku atau bahan sastra yang disimpan, dikatakan sebagai sebuah "perpustakaan". Makna ini masih menganut makna perpustakaan di tahun sebelumnya.

Pada tahun 1981 representasi perpustakaan sedikit berubah. Seperti nampak berikut ini:

building itself given over to books, manuscripts, musical scores, or other literary and sometimes artistic materials (as paintings or musical recordings) kept in some convenient order for use but not for sale. "(Encyclopedia Britannica, 1981)
Pada tahun 1981 ini makna perpustakaan merupakan sebuah ruang, bagian dari gedung, atau gedung itu sendiri yang berisi koleksi buku, manuskrip, material musik, bahan sastra dan materi artistik (seni) baik berbentuk cetak maupun rekaman. Semua jenis materi yang disimpan tersebut untuk digunakan dan tidak untuk dijual.

Makna perpustakaan, masih menyebutkan bahwa perpustakaan merupakan ruang, bagian ruang, atau gedung. Hal ini masih sama dengan makna perpustakaan pada tahun-tahun sebelumnya. Terdapat perubahan makna dari sebelumnya, yang menyebutkan variasi jenis bahan yang disimpan di perpustakaan lebih banyak. Jika sebelumnya koleksi yang disimpan hanya berupa buku, bahan sastra dan material referensi, sudah bertambah dengan disebutnya; manuskrip, material musik, serta karya berbentuk rekaman.

Masih pada tahun 1980-an, yaitu pada tahun 1983, representasi perpustakaan melalui bahasa menyebutkan bahwa:

"Library is a place set apart to contain books and other material for reading, study, or reference, as a room, set of room, or building where books may be read or borrowed." (The Random House Dictionary of The English Language, 1983)

Makna ini menekankan pada perpustakaan sebagai tempat untuk membaca, belajar, dan membaca buku-buku referensi, yang tersimpan di dalamnya.

Menurut Surat Edaran Bersama (SEB) Mendikbud dan Kepala BAKN Nomor 53649/MPKJ1988 dan Nomor 14/SE/1988 tentang Jabatan Fungsional Pustakawan disebutkan bahwa:

"Perpustakaan adalah lembaga, kantor atau unit kerja lain yang sekurangkurangnya memiliki 1.000 (seribu) judul bahan pustaka yang terdiri dari sekurangkurangnya 2.500 (dua ribu lima ratus) eksemplar yang dibentuk dengan keputusan pejabatyang berwenang" 
Makna perpustakaan sesuai dengan Surat Edaran Bersama tersebut, memberikan keterangan cukup memadai tentang makna perpustakaan. Jumlah koleksi 1.000 judul dan 2.500 eksemplar menjadi satu syarat sebuah koleksi yang terkumpul dikatakan sebagai sebuah perpustakaan, dengan dilegalkan keputusan pejabat yang berwenang.

Makna perpustakaan pada tahun 1990, berubah dengan munculnya film, sebagai koleksi yang disimpan di perpustakaan. Hal ini seperti tertulis:

"Library is a place in which literary, musical, artistic or reference materials (as books, manuscripts, recordings, or films) are kept for use but not for sale" (The concise oxford dictionary of current english, 1990)

Sedangkan di Indonesia, makna perpustakaan pada tahun 1990, menyebutkan bahwa "Perpustakaan adalah kumpulan bukubuku"(Departemen Pendidikan dan Kebudayaan, 1990), belum menyebutkan koleksi jenis lainnya.

Hal ini juga sama dengan representasi perpustakaan dalam (Kebudayaan Departemen Pendidikan, 1990) "perpustakaan adalah kumpulan buku-buku (bacaan dsb)".

Dua makna yang sama tersebut menunjukkan perbedaan makna dalam tahun yang sama di Indonesia dan di luar Indonesia. Di luar Indonesia makna perpustakaan dengan berbagai jenis material yang disimpan, digunakan dan dipinjam, namun di Indonesia makna perpustakaan masih terbatas pada kumpulan buku-buku. Sesuai dengan yang disampaikan oleh Hall (2003) bahwa representasi melibatkan tiga perintah yang berbeda yaitu benda, peristiwa, orang atau pengalaman; konsep mental yang ada di kepala kita dan tanda-tanda. Dengan demikian peristiwa, pengalaman atau orang yang berbeda dengan konsep mental tentang perpustakaan berbeda, maka akan menghasilkan makna yang berbeda, walaupun pada saat yang sama.

Selanjutnya muncul representasi perpustakaan yang disampaikan oleh penulis
Indonesia, (Sulistyo-Basuki, 1991) dalam bukunya Pengantar Ilmu Perpustakaan menyatakan bahwa:

"Perpustakaan adalah sebuah ruangan, bagian sebuah gedung, ataupun gedung itu sendiri yang digunakan untuk menyimpan buku ataupun terbitan lainnya yang biasanya disimpan dengan tata susunan tertentu untuk digunakan pembaca, bukan untuk dijual"

Representasi perpustakaan tersebut menunjukkan perkembangannya, memaparkan lebih detail tentang perpustakaan. Walaupun bahan material yang disimpan di perpustakaan tidak dijelaskan lebih detail. Disebutkan pula bagaimana buku di perpustakaan diatur dan ditata dengan susunan atau cara tertentu. Untuk siapa bahan buku dan terbitan lain di perpustakaan, juga dijelaskan bahwa untuk digunakan pembaca. Ada unsur pembaca dan seseorang yang melakukan penyusunan buku. Jadi perpustakaan bukan hanya tempat buku disimpan saja, namun dalam proses penyimpanan itu buku-buku disusun dengan cara tertentu. Hal ini tidak muncul pada makna perpustakaan pada tahun sebelumnya. Perpustakaan bukan hanya sebagai gudang buku, teronggok begitu saja, namun buku yang disimpan tersebut kemudian direncanakan untuk dibaca atau digunakan oleh pembacanya. Pada tahun 1996 Zaini mengungkapkan bahwa:

\section{"Perpustakaan mernpakan suatu unit penunjang teknis, yang tugas utamanya adalah turut menyediakan dan menciptakan kondisi yang stimulatif bagi terlaksananya proses belajar mengajar".}

Makna perpustakaan ini, tidak menekankan kepada koleksi, namun pada tugas utama sebagai unit penunjang dalam proses belajarmengajar. Jika sebelumnya Sulisyo-Basuki menekankan pada penggunaan buku untuk pembacanya, (Zaini, 1996) menekankan kepada bagaimana perpustakaan menyediakan kondisi yang stimulatif untuk proses belajar-mengajar. 
Makna perpustakaan sebagai sarana penyediaan informasi dan pelestarian kebudayaan, muncul pada representasi perpustakaan pada tahun 1998:

\section{"Perpustakaan merupakan sarana penyediaan informasi dan pelestarian kebudayaan yang berperan penting untuk keperluan pendidikan, penelitian dan pengembangan ilmu pada pembangunan nasional" (Hardjoprakoso, 1998).}

Istilah informasi menggantikan berbagai bahan pustaka, buku, bahan sastra, karya rekaman, karya seni, film dan material lainnya yang sudah disebutkan pada makna perpustakaan sebelumnya. Koleksi perpustakaan lebih ditekankan pada kandungan di dalamnya yakni informasi, bukan lagi kepada bentuk fisik luarnya.

Di sisi lain, berbagai literatur menggabungkan kata perpustakaan dengan kata "Digital", menjadi kata "digital library"

"Digital library is a collection of textual, numeric data, scanned images, graphics, audio \& video recordings that provides access to digital collection for ease of retrieval of information to the users".(Cleveland, 1998)

Konsep "digital library” ini dalam komunitas perpustakaan ditunjukkan dalam beberapa frasa seperti electronic library, virtual library, library without walls. Penggunaan frasa tersebut bergantian digunakan untuk merujuk pada konsep digital library.

Teknologi informasi dan komunikasi yang terus berkembang, mempengaruhi makna perpustakaan. Perpustakaan dikaitkan dengan media dan tool yang digunakan di dalam layanan perpustakaan. Perpustakaan dengan memanfaatkan teknologi digital tidak mungkin lagi dielakkan, sehingga memunculkan konsepkonsep perpustakaan yang berubah atau bertambah. Konsep perpustakaan digital, perpustakaan virtual dan perpustakaan elektronik, muncul disebabkan penggunaan teknologi baru atau teknologi digital di perpustakaan. Hal ini menunjukkan bahwa perpustakaan adalah sebuah makna yang terus akan berubah.

Telah muncul konsep digital library (Cleveland, 1998) pada literatur di luar Indonesia. Di Indonesia makna perpustakaan pada tahun 2000-an kembali masih dengan makna perpustakaan sebagai tempat buku dan media belajar seperti disampaikan oleh Darmono, (2001):

"Perpustakaan diartikan sebagai tempat kumpulan buku-buku atau tempat bukubuku dihimpun dan diorganisasikan sebagai media belajar siswa"

Darmono (2001) menggunakan konsep "dihimpun dan diorganisasikan" dapat dimaknai pula sama dengan yang disampaikan oleh Sulistyo-basuki (1991) bahwa buku-buku disusun dengan aturan tertentu. Namun representasi ini berkembang dengan menambahkan konsep "media belajar siswa" , dapat dimaknai pula bahwa perpustakaan sebagai media untuk belajar bagi siswa.

Makna perpustakaan yang masih tidak jauh berbeda dengan makna yang disampaikan Sulistyo-Basuki adalah makna perpustakaan oleh Sutarno (2006) yang menyatakan bahwa:

"Perpustakaan adalah mencakup suatu ruang, bagian dari gedung/bangunan atau gedung tersendiri yang berisi buku-buku koleksi, yang diatur dan disusun demikian rupa, sehingga mudah untuk dicari dan dipergunakan apabila sewaktu-waktu diperlukan oleh pembaca."

Representasi tersebut selain menjelaskan perpustakaan sebagai sebuah tempat sama dengan yang disampaikan oleh Sulistyo-Basuki (1991), dan juga memberikan penekanan pada kemudahan orang yang akan membaca buku di perpustakaan dalam menemukan buku yang akan mereka baca.

Nampaknya sampai pada tahun 2006, definisi di beberapa buku bidang perpustakaan di Indonesia belum memberikan definisi perpustakaan yang signifikan berubah. Definisi 
-definisi “perpustakaan" tersebut sebagai representasi perpustakaan, dimana konsep ini dapat digunakan untuk merujuk obyek perpustakaan "nyata". Dalam sistem representasi perpustakaan, konsep "perpustakaan" dihubungkan dengan ruangan atau bagian sebuah ruangan, buku atau koleksi, aturan penyusunan, pembaca, tempat atau media belajar, penyediaan informasi, pendidikan, penelitian dan pengembangan ilmu.

Bahasa merupakan sistem representasi kedua yang terlibat dalam konstruksi makna (Hall, 2003). Melalui bahasa pada wacana perpustakaan, merupakan sistem representasi yang berupaya mengkonstruksi makna perpustakaan. Gagasan atau konsep perpustakaan dikonstruksi dalam wacana perpustakaan dengan menggunakan bahasa. Perpustakaan dapat ditafsirkan atau dimaknai melalui representasi.

Pada tahun 2007, muncul Undang-Undang Perpustakaan, yaitu Undang-Undang Nomor 43 tahun 2007. Di dalam Undang-Undang tersebut disebutkan representasi perpustakaan sebagai berikut:

"Perpustakaan adalah institusi pengelola koleksi karya tulis, karya cetak, dan/atau karya rekam secara profesional dengan sistem yang baku guna memenuhi kebutuhan pendidikan, penelitian, pelestarian, informasi, dan rekreasi para pemustaka".

Representasi tersebut memberikan penekanan perubahan dari makna sebelumnya pada:

1. Perpustakaan tidak lagi dimaknai sebagai tempat, ruang, gedung, atau bagian dari ruang atau gedung itu sendiri. Perpustakaan merupakan sebuah institusi yang melakukan pengelolaan koleksi.

2. Koleksi yang dikelola tidak disebutkan sebagai buku, bahan sastra, manuskrip, karya artistik, musik, film dan sebagainya, seperti halnya makna pada tahun sebelumnya. Koleksi yang dikelola disebutkan dengan karya tulis, karya cetak dan atau karya rekam.
3. Jika sebelumnya makna koleksi yang ada, diatur dengan aturan tertentu, pada Undang-Undang Nomor 43 Tahun 2007, diterangkan dengan "pengelolaan koleksi secara professional dengan sistem yang baku”. Hal ini dapat dimaknai bahwa pengelolaan koleksi yang ada di perpustakaan dilakukan oleh staf-staf profesional. Disebutkan guna "memenuhi kebutuhan" dapat dimaknai bahwa ada pembaca atau pengunjung perpustakaan.

4. Tujuan pemanfaatan koleksi. Jika pada definisi sebelumya bahwa perpustakaan sebagai media belajar, pendidikan, penelitian, namun pada definisi ini muncul makna yang lebih luas atas peran perpustakaan. Perpustakaan tidak hanya sebagai tempat belajar saja, namun juga memenuhi kebutuhan informasi dan rekreasi bagi para pengunjung. Perpustakaan memenuhi kebutuhan pendidikan, juga telah disebutkan oleh (Asheim, 1985) pada artikelnya yang berjudul "International Values in American Librarianship". Artinya, peran perpustakaan guna memenuhi peran pendidikan, sudah didengungkan oleh Asheim di tahun 1985, sementara di Indonesia, peran itu baru dituangkan dalam literatur Hardjoprakoso (1998).

Penekanan pada peran perpustakaan dalam pemenuhan kebutuhan pendidikan, penelitian, pelestarian, informasi dan rekreasi bagi pemustaka merupakan fungsi baru yang dikonstruksi oleh pengambil kebijakan dalam hal ini pemerintah. Melalui Undang-Undang Nomor 43 Tahun 2007 , pemerintah memproduksi makna perpustakaan. Kontruksi makna perpustakaan yang diinginkan pemerintah adalah yang berfungsi atau berguna memenuhi kebutuhan pendidikan, penelitian, pelestarian, informasi dan rekreasi. Konsepkonsep ini berhubungan atau terkait erat dengan "Perpustakaan". Hal ini semakin meyakinkan kita bahwa makna perpustakaan dikontruksi dan dapat berubah. 
Applegate (2009) dalam artikelnya menuliskan:

"The library is a campus space, one uniquely suited to meet important student needs for space as well as services and resources".

Perpustakaan merupakan suatu ruang kampus yang unik, mempertemukan kebutuhan siswa terhadap ruang, layanan dan berbagai sumber daya yang diperlukan. Makna ini memiliki perubahan yang signifikan dengan makna sebelumnya, dengan menyebut sebagai ruang kampus yang unik serta menyebutkan layanan dan sumber daya. Artinya, sumber daya tidak terbatas pada koleksi karya tulis, karya cetak, dan karya rekam, namun mencakup semua sumber daya yang ada di perpustakaan.

Konstruksi makna perpustakaan, hampir sama seperti pada Undang-Undang nomor 43 Tahun 2007, dituliskan oleh Subrata (2009)

"Perpustakaan merupakan unit kerja yang menghimpun, mengelola dan menyajikan kekayaan intelektual untuk kepentingan pendidikan, penelitian, pelestarian, informasi, dan rekreasi untuk mencerdaskan kehidupan bangsa."

Dalam standar perpustakaan SNI 7495:2009 tentang Perpustakaan Umum Kabupaten /kota, perpustakaan direpresentasikan sebagai:

"suatu institusi yang mengelola materi perpustakaan yang diorganisir secara sistematis dengan aturan baku, dilayankan untuk kepentingan pendidikan, penelitian, pelestarian, informasi dan rekreasi para penggunanya".

Pada dua representasi perpustakaan tersebut, tidak lagi menyebut perpustakaan sebagai sebuah ruang, bagian ruang atau gedung, maupun gedung sendiri, namun disebutkan bahwa perpustakaan adalah suatu unit kerja atau institusi. Koleksi yang disimpan untuk kepentingan, pendidikan, penelitian, pelestarian, informasi dan rekreasi, tidak juga disebut sebagai karya tulis, karya cetak dan atau karya rekam, namun menyebutkan sebagai kekayaan intelektual dan materi perpustakaan. Kekayaan intelektual barangkali dimaksudkan bahwa semua bahan yang tersimpan di perpustakaan, memiliki nilai pengetahuan yang bermanfaat bagi pemustaka.

Terkait dengan pemanfaatan materi perpustakaan dan karya intelektual yang dikelola perpustakaan, guna memenuhi "kepentingan pendidikan, penelitian, pelestarian, informasi dan rekreasi para penggunanya", hal ini sama dengan apa yang disampaikan dalam Undang-Undang Nomor 43 Tahun 2007 (Sekretariat Negara RI, 2007).

Makna perpustakaan yang tertuang di dalam Undang-Undang Nomor 43 Tahun 2007, tertuang dalam hampir semua peraturan yang terkait dengan kepustakawanan. Sebagai contoh, makna perpustakaan tersebut tertuang pula pada:

a. Peraturan Kepala Perpustakaan Nasional Republik Indonesia Nomor 11 Tahun 2015 tentang Petunjuk Teknis Jabatan Fungsional Pustakawan dan Angka Kreditnya.

b. Peraturan Menteri Pendayagunaan Aparatur Negara dan Reformasi Birokrasi RI Nomor 9 tahun 2014 tentang Jabatan Fungsional Pustakawan dan angka Kreditnya.

c. Peraturan Pemerintah Republik Indonesia Nomor 24 Tahun 2014 tentang Pelaksanaan Undang-Undang Nomor 43 Tahun 2007 tentang perpustakaan.

Dengan bahasa seseorang membangun gambaran realitas disekitarnya. Makna perpustakaan seperti pada UU No. 43 Tahun 2007 dikonstruksi melalui bahasa yang dituangkan dalam berbagai pedoman dan peraturan turunannya.

Makna tersebut kemudian diacu oleh dunia kepustakawanan Indonesia, pustakawan, pengelola perpustakaan serta institusi perpustakaan dan masyarakat yang lebih luas. Walaupun seperti yang telah disampaikan di atas, bahwa penggunaan istilah koleksi yang disimpan ada beberapa perubahan istilah penggunaan, dengan kata "materi perpustakaan" dan "karya intelektual". 
Makna perpustakaan di Indonesia semakin berkembang. Dalam beberapa literatur. Peneliti menemukan makna perpustakaan sebagai berikut:

\section{"Perpustakaan adalah suatu organisasi yang bertugas mengumpulkan informasi, mengolah, menyajikan, dan melayani kebutuhan informasi bagi pemakai perpustakaan"(Mangnga, 2015).}

Muncul istilah "informasi” untuk menyebutkan, buku (bahan materi lain), karya tulis, karya cetak, karya rekam, materi perpustakaan, dan karya intelektual. Demikian juga pada representasi di bawah ini:

"Perpustakaan merupakan institusi yang menyediakan jasa layanan Informasi" (Wardah, 2017)

Kata "informasi" menggantikan banyak konsep yang sebelumnya digunakan dalam menyebut koleksi perpustakaan, seperti buku, bahan sastra, manuskrip, karya artistik, karya tulis, karya cetak, karya rekam,film, semua materi perpustakaan, dan karya intelektual, yang sebelumnya disimpan di perpustakaan. Makna perpustakaan yang disampaikan oleh (Wardah, 2017), tidak menyebutkan tujuan penyediaan jasa layanan informasi.

\section{E. KESIMPULAN}

Berdasarkan perubahan makna perpustakaan di atas, maka dapat disimpulkan bahwa perpustakaan adalah sebuah ruang atau institusi, tempat dikumpulkannya berbagai informasi, serta mempertemukan berbagai kebutuhan pemustaka, terhadap ruang, layanan, dan berbagai sumberdaya, untuk kepentingan pendidikan, penelitian, informasi dan rekreasi. Namun di sisi lain perpustakaan menghadapi terpaan perkembangan teknologi, komunikasi dan informasi sehingga memunculkan berbagai konsep tentang perpustakaan digital, perpustakaan tanpa dinding dan berbagai istilah yang semakna dengan itu.
Berbagai perubahan makna perpustakaan dari waktu ke waktu menunjukkan bahwa representasi perpustakaan melalui bahasa mengalami perubahan. Makna mutakhir perpustakaan yang disimpulkan dalam penelitian, akan terus mengalami perubahan. Perpustakaan merupakan makna, yang dapat berubah dan dikontruksi.

\section{DAFTAR PUSTAKA}

Applegate, R. (2009). The library is for studying: Student preferences for study space. The Journal of Academic Librarianship, 35(4), 341-346.

Aprinta, G. (2011). Kajian media massa: Representasi girl power wanita modern dalam media online (Studi framing girl power dalam rubrik karir dan keuangan Femina online). Jurnal The Messenger: Cilture Studies, IMC and Media, 3(1), 12-27.

Asheim, L. (1985). International values in American librarianship. The Journal of Library History, 20(2), 186-195.

Cleveland, G. (1998). Digital libraries: Definitions, issues and challenges. Retrieved May 12,2018 from https://archive.ifla.org/VI/5/op/udtop8/udtop8.pdf

Collins English Dictionary - Complete \& Unabridged 10th Edition. (1979). Retrieved March 5, 2018 from http:// www.dictionary.com/browse/library

Darmono. (2001). Manajemen dan tata perpustakaan sekolah. Jakarta: Gramedia Widiasarana Indonesia.

Departemen Pendidikan dan Kebudayaan. (1990). Kamus besar bahasa Indonesia. Jakarta: Balai Pustaka.

Fowler, H. W., Fowler, F. G., \& Allen, R. E. (1990). The concise oxford dictionary of current english. (H. W. Fowler, F. G. Fowler, \& R. E. Allen, Eds.). New York: Oxford University Press.

Hall, S. (2003). The Work of Representation. In S. Hall (Ed.), Representation: Cultural Representations and Signifying Practice (pp. 13-74). London: Sage Publication. 
Hardjoprakoso, M. (1998). Kebijakan Sistem Nasional Perpustakaan di Indonesia. In E. Koswara (Ed.), Dinamika Informasi dalam Era Global (pp. 1-15). Bandung: PT. Remaja Rosdakarya Offset.

Kawindra, F. R. (2013). Makna perpustakaan sekolah (Studi fenomenologi tentang makna perpustakaan sekolah oleh kepala SMA negeri di kabupaten Jember). Skripsi Universitas Airlangga. Diakses dari http://repository.unair.ac.id/16301/ Kumbara, A. A. N. A. (2018). Genealogi teori dan metodologi di cultural studies. Jurnal Studi Kultural, 3(1), 35-46.

Macmillan. (1973). Dictionary. New York: Macmillan Publishing.

Mangnga, A. (2015). Peran perpustakaan sekolah terhadap proses belajar mengajar di sekolah. Jupiter, 14(1), 38-41.

Merriam-Webster. (Ed.). (1981). Webster's third new international dictionary of the English language unabridged. Philippines Copyright: G \& C. Merriam CO. --

Pradana, D. A. (2014, July). Makna perpustakaan bagi anak jalanan (Studi deskriptif pada rumah belajar pandawa di Surabaya). Skripsi - Universitas Airlangga. Diakses dari http://repository. unair.ac.id/15794/

Saleh, A. R. (2010). Perpustakaan digital: Kesinambungan dan dinamika. Jurnal Pustakawan Indonesia, 10(1), 59-61.

Saputra, N. D., Damayani, N. A., \& Rahman, A. S. (2017). Kontruksi makna pegiat perpustakaan jalanan (studi fenomenologi tentang kontruksi makna pegiat perpustakaan jalanan di kota Bandung). Khizanah Al-Hikmah Jurnal Ilmu Perpustakaan, Informasi, Dan Kearsipan, 5(2), 152-159.

Sekretariat Negara RI. Undang-Undang Republik Indonesia nomor 43 tahun 2017 tentang perpustakaan. (2007). Diakses 30 April 2018, http://htl.unhas.ac.id/ form_peraturan/photo/094607-UU No.43 tahun 2007 tentang Perpustakaan.pdf
Subrata, G. (2009). Perpustakaan digital. Diakses 9 Mei 2018, http://lib.mic.ac.id/ perpus/Makalah/KM Perpustakaan-2.pdf()

Sulistyo-Basuki. (1991). Pengantar ilmu perpustakaan. Jakarta: Gramedia Pustaka Utama.

Sutarno. (2006). Perpustakaan dan masyarakat. Jakarta: Sagung Seto.

Stein, J., \& Urdang, L. (Eds.). (1983). The Random House Dictionary of The English Language. New York: Random House.

The world Publishing Company. (1970). Webster's new world dictionary. New York: Prentice-Hall.

Tucker, J. M., \& Goedeken, E. A. (2017). History of Libraries. In W. A. Wiegand \& D. G. Davis (Eds.), Encyclopedia of History Libraries (pp. 1796-1811).

Utami, F. A. (2016). Konstruksi sosial masyarakat mengenai perpustakaan desa di Surabaya. Universitas Airlangga.

Vacliuca, Q., \& Yasir, Y. (2016). Representasi gaya hidup mahasiswa dalam novel good memories karya Lia Indra Andriana. Jurnal Online Mahasiswa Fakultas Ilmu Sosial dan Ilmu Politik Universitas Riau, 3(2), 1-15.

Wardah, M. W. (2017). Implementasi ISO 9001:2008 menuju library continual quality improvement di perpustakaan Universitas Sanata Dharma Yogyakarta. Info Persadha, 15(1), 24-38.

Wuryanto, A. G. (2016). Representasi perempuan berhijab dalam iklan Wardah versi "girls day out", exclusive series, dan "perfect match". Skripsi - Universitas Airlangga. Diakses dari http://repository. unair.ac.id/41252/

Yusnita, C. (2012, September 17). Makna perpustakaan sekolah bagi penyandang tunanetra di yayasan pendidikan anak. Skripsi - Universitas Airlangga. Diakses dari http://repository.unair.ac.id/15475/

Zaini, A. (1996). Peranan dan tantangan perpustakaan di perguruan tinggi. $\mathrm{Al}$ Qalam, 11(58), 30-35. 